\title{
Administrative Capacity as a Constraint to Fiscal Decentralization The Case of Romania and Poland
}

\author{
Dana Georgeta Alexandru \\ Ph.D., Associate Professor at the Lucian Blaga University of Sibiu \\ Faculty of Social and Human Sciences, Sibiu, Romania \\ e-mail: dana.alexandru@ulbsibiu.ro
}

\author{
Beata Guziejewska \\ Ph.D., Associate Professor at the University of Lodz \\ Faculty of Economics and Sociology, Department of Public Finance, Lodz, Poland \\ e-mail: beata.guziejewska@uni.lodz.pl
}

\section{Abstract}

This paper considers the problem of administrative capacity as one of the main requirements that the accession countries seeking EU membership had to meet, and as a prerequisite to the decentralization of their public sectors and public finances. The selected decentralization problems are analyzed using the cases of two countries: Romania and Poland. The results of a theoretical and practical evaluation of administrative capacity as a likely obstacle to fiscal decentralization are presented taking account of the different levels of decentralization in Poland and Romania. A comparative analysis of Romania and Poland shows that administrative capacity can be a constraint for fiscal decentralization. In Poland, the main problem is that the local authorities have not yet been granted powers over taxes that are more complicated to administer in legal and financial terms. Romania has the problem of the incomplete devolution of powers and the limited financial independence of local governments, which basically means that the principle of subsidiarity is insufficiently implemented.

Keywords: public administration, local taxes, fiscal decentralization, local selfgovernment

JEL: H70, H71, H77 


\section{Introduction}

Romania and Poland are two post-communist countries that launched determined efforts to establish the rule of democracy, introduce market economy principles, and decentralize their administrations and public finances. Even though Poland is more advanced on the path of financial decentralization, the level of devolution, and the fiscal autonomy of local governments are still limited. In Romania, public finances and the organization of administration are still strongly centralized. The main source of funding for local governments in both countries is property taxes and "shared taxes" supported by general grants and specific grants from the state budget, special funds, and EU funds.

In both Poland and Romania, fiscal decentralization has encountered many problems. Some of them are political while others are objective, for instance, organizational and administrative constraints, which are partly due to the unitary system of government in the two countries. This study focuses on the administrative constraints as an objective obstacle arising at different stages of decentralization. A comparative analysis of local finance systems in Poland and Romania is performed to formulate synthetic conclusions about administrative constraints associated with the studied aspects of fiscal decentralization. The study's interest in decentralization is due to the fact that of the two aspects of local financial autonomy - collecting revenue and spending - the first one tends to be more problematic. The main thesis tested in the paper is that administrative capacity can be a barrier at different stages of fiscal decentralization: lower in Romania and higher in Poland. The conclusions from the research are formulated, taking account of the fact that Poland and Romania are at different points of fiscal and administrative decentralization.

While local governments' own revenues represent a considerable proportion of their total incomes in Romania, their finances are still strongly dependent on the central government. The 2016 expenditures and revenues of Romanian municipalities accounted respectively for $28 \%$ and $30.5 \%$ of total public expenditures and revenues. In the period 2015-2016, they were estimated at $8.9-10.02 \%$ of Romanian GDP. Poland's rates were more favorable, but the country's local finance system is criticized for a large number of revenue transfers from the state budget and for local shares of PIT (Personal Income Tax) and CIT (Corporate Income Tax) revenues with the status of local authorities' own revenues. The research presented in this paper uses quantitative analysis to mainly study the local financial system and the challenges faced by Romania as a less advanced country in the area of decentralization.

An argument for the paper is the scarcity of the analysis of administrative capacity in relation to legislative changes and the effects of fiscal decentralization. In this context, the paper aims to investigate the scale of change in the system of financing local government and its relationship with the equalities and differences between different public administration levels. For this purpose, our objectives were the following: (a) to analyze changes in the fiscal decentralization system; (b) to investigate 
if administrative capacity should continue to be considered a solution to continue and deepen the process of fiscal decentralization, and (c) to evaluate the influence of legislation changes on the local tax system and the prerogatives of local authorities in this area.

The outcomes will be valuable to both policy and decision-makers in understanding the effects that fiscal decentralization can have on the development of a coherent local fiscal system. Moreover, the present paper should bring knowledge of both the provision of local tax systems and the valuation and taxation of property, and the better management of distributing public money.

This article is both theoretical and empirical. It consists of five parts: an introduction, a theoretical part concerning administrative capacity, then the legal framework of public administration and public finance in both countries, and statistical analysis of the scope of local taxes in Romania and Poland. The article ends with conclusions.

\section{Administrative capacity: the meaning of the term and its practical importance}

The administrative capacity of local government was one of the core elements of the EU enlargement process. This concept can be used as a theoretical framework for the assessment of the current stage of local government performance in Romania and Poland. Since 1997, administrative capacity has grown in importance and complexity as one of the main requirements that states have to meet in the process of joining the EU. In these circumstances, the European approach to administrative capacity is related to the implementation of the acquis in various areas, such as the single market, competition, and so on. From a wide perspective (OECD 1995), administrative capacity "is the process by which individuals, groups, organizations, and societies increase their abilities to (i) perform core functions, solve problems, define and achieve objectives; and (ii) understand and deal with their development needs in a broad context and in a sustainable manner."

However, the concept of capacity development acquires a new meaning "that suggests a shift from building capabilities towards enhancement and strengthening of existing capacities" (Dragoș and Neamțu 2007, p. 646). Administrative capacity requirements should lead to the success of institution-building in post-Communist states' public administrations. The Commission defines Institution-building as a "developing the structures and systems, human resources and management skills needed to implement the acquis" (Dimitrova 2002, p. 178). In brief, administrative capacity assumes the management capabilities of local governments (Petak 2006, p. 85), which means policy management, resource management, and program management (Gargan 1981, p. 652). According to El-Taliawi and Van Der Wal (2019, pp. 243-257), administrative capacity is necessary for both achieving public policy success and preventing poli- 
cy fiascos. Capacity is a continuous process (with the country's historical trajectory), which includes enhancing administrative autonomy and competence, arrangements incentivizing coordination and collaboration, safeguarding with adequate oversight and control.

Administrative capacity seems to be a big challenge of policy design over time and contextual dimensions of the space (Howlett 2019, pp. 275-284).

The concept of "administrative capacity" acts to rule the distribution of competencies to the local level. It was argued (Dragoș and Neamțu 2007, p. 639) that the use of this concept has been helpful, because "decentralization policy looked at all local government entities as equal holders of decentralized competencies, although their administrative capacity was quite different." On the other hand, ensuring the same quality of public services requires the transfer of the existing, central-managed competencies to the level of local government entities that are able to manage the competencies satisfactorily. ${ }^{1}$

The reform of decentralization managed in Romania in 2006 showed that this process was an unfinished project: local units had to provide the means for some public service, but they had no opportunity to organize them. ${ }^{2}$ In other cases, the transfer was incomplete because of the lack of financial means to realize the task. ${ }^{3}$ In Poland, there is a problem with insufficient local taxes and transfers.

Administrative capacity also varies depending on the size of the community. The size of local government entities is one of the core elements in assessing the basic unit's effectiveness. Therefore, the different levels of government must interact closely in order to exercise both their responsibilities and tasks by the lowest level of government. The distribution of competencies is selected in connection with the efficiency of the public service supply in a decentralized manner and the size of local government entities. The allocation of responsibilities should be accompanied by the transfer of the corresponding financing, and the authorities should consider rationalizing the public expenditure, clarifying and strengthening the tasks between government tiers.

Communities need to make a concerted effort to bridge this gap, as they are forced to find a way to fund the basic legal functions because all formulas in the equalization system are based on income tax, population, county area, and urbanized area. No weight is given to any indicators of expenditure needs like population density, geographical position, or development level. Income tax per capita is used in most formulas as a proxy for economic development. Therefore, it is almost impossible for these communities to generate their own resources to sustain development. In this context,

1 In Romania, when local public authorities from communes do not have the capacity to receive such competencies, the next level (county) will receive the competencies instead.

2 For instance, schools are maintained by the local public authorities, but when a new school is established, the management of the school and the curriculum are centralized.

3 For instance, national roads that pass the communes and cities should be maintained by the local authorities, even though they are used by the nation as a whole and not only by the inhabitants of that city/commune. 
efforts should be made towards creating joint bodies between local government entities that could better manage the supply of local public services. This solution would solve the financial aspect of local expenditures and would also strengthen the capacity of the entities by sharing the tasks. Unlike Romania, in Poland, the equalization system is designed to allocate more funding to poorer municipalities. It was argued (Kulesza and Sześciło 2012, p. 499) that this "mechanism has become an instrument of the cohesion policy and raises concerns in wealthier regions and municipalities that are reluctant to support less developed areas". These circumstances emphasize the capacity of local government entities to exercise their competencies in the interests of the community and the degree of their dependence on or autonomy from the central or regional government.

Three main dimensions of tax autonomy and competencies in public revenues have been identified in the literature (Musgrave and Musgrave 1980, Ahmad and Brosio 2015):

- Which level of government has the right to choose the taxes that this given level can impose?

- Which level of government can legislate over the structure of the tax bases and which level has the discretion to set the tax rates?

- Which level of government is put in charge of administering the individual taxes?

The competencies which can be assigned to different levels of public authorities in the area of taxes are also formulated as (Borodo 1997, p. 17): the competence to legislate, the competence to take over the tax revenue, and the competence to administer the various taxes. In the case of both countries, we have the problem of limited decentralization and limited "real" local taxes. In Poland and Romania, shared taxes play an important role in local revenues, but in this case the local authorities have no competence to impose the tax and to affect its structure.

\section{Decentralization of public finance. The legal framework in both countries}

The system of financing local government in Romania is based on Law 273/2006 on local public finance. The law regulates the procedure of elaborating, approving, and executing the local budget and the most important aspects related to the structure and criteria for the transfer of quotas and amounts correcting imbalances that occur at the local level. These regulations are supported by the Tax Code, ${ }^{4}$ Title IX provisions, which set out the legal framework of the structure of taxes and local fees in Romania. According to the Romanian regulations in force, there are taxes and fees that are covered exclusively by the local budgets, others that are covered by the state budget only, as well as some which are shared by the local and state budgets.

4 Adopted by Law 227/2015. 
Local budgets' own revenues represent the main category because all local budgets have such incomes. These can be divided into three main categories:

1. Local taxes and fees - taxes established by the Fiscal Code.

2. Rates from income tax - the most important local revenues.

3. Other local own revenues.

The Romanian local budgeting system consists of 41 county budgets and over 3,000 municipality budgets (including the General Budget of the Bucharest Municipality and the six separate district-level budgets corresponding to the six administrative parts of the Bucharest Municipality). Romanian counties are the administrative-territorial units at the intermediate level, while communes, towns, and municipalities (cities) form the local administrative level. From a budgetary point of view, the tasks are clearly separated by law.

The main categories of own local revenues are presented below:

- Building tax.

- Land tax.

- The fee on means of transport.

- Hotel fees.

- The tax on shows.

- Fee for the issuance of certificates, permits, and authorizations.

- Fee for using means of advertising and publicity.

- Rates from income tax.

- Property revenue.

- Revenue from service supplies.

- Fines and penalties.

- Capital revenue.

- Financial operations.

The preponderance of own local revenues in total local revenues varies greatly. In many situations, the excluded amounts of VAT transferred from the state budget and subsidies from other public budgets (like the unemployment budget or health insurance budget) are less important than the own local revenues.

1. Local taxes and fees. Every person - be it a corporate entity or a natural person - who holds the ownership title in a building in Romania has to pay an annual tax on that building. The tax on building applies to all entities that use a public or private property asset of the administrative and territorial unit. The Tax Code makes a distinction ${ }^{5}$ between these taxes depending on whether the taxpayer is a corporate entity or a natural person, which is specific only to this type of tax and not applicable to other categories of local taxes and fees.

5 For residential buildings and annexes which are the property of natural persons the tax on buildings is calculated by applying a 0.08-0.2 percent on the taxable value of that building; non-residential buildings which are the property or are held by corporate entities are subject to a tax on buildings to be calculated by applying a percentage of $0.2-1.3$, inclusively, on the taxable value of that building. 
The amount of local taxes and fees is determined by the decision of the local council and is payable on a yearly basis, in two installments, the latest on March $31^{\text {st }}$ and September $30^{\text {th }}$, respectively.

Similarly, every corporate entity or natural person who holds the ownership title to a piece of land has to pay a tax on that land to the local budget in the jurisdiction where the land is located. The land tax is calculated based on its surface, the rank of the locality where it is located, and its surface and category, as per the classification provided by the local council based on scoring grids.

Any person that owns a means of transport that is required to be registered in Romania owes an annual fee for the means of transport. The income from the tax on specific means, penalties for unpaid fines and the applicable fines may only be used for maintenance, repair, and construction works for local and county roads. Sixty percent of these amounts represent income to the local budget, and the remaining $40 \%$ represents income to the county budget.

Each person who needs to obtain certificates, permits, or authorizations is required to pay a fee to the relevant local public administration department before it is issued. The fees due for issuance of urbanism certificates and building permits by the chairmen of county councils, which are subject to the approval of the mayors' offices of communes, are transferred as follows: 50\% goes to the local budgets of the communes and $50 \%$ to the local county budget.

Every person who benefits from advertising and publicity services in Romania based on a contract or other arrangement with another person has to pay a charge, except for the advertising and publicity services that are provided through written and audiovisual mass dissemination means.

The organizers of artistic performances, sporting competitions, or other entertainment activities in Romania have to pay tax on shows. The tax on shows is payable to the local budget of the administrative and territorial unit where the performance, competition, or leisure activity takes place.

The local and county councils and the General Council of the Bucharest Municipality, as appropriate, may apply special fees for the proper operation of some local public services dedicated to natural persons and corporate entities as well as for the promotion of tourism in localities. For instance, the Tax Code allows tourism operators to charge some amounts for tourist accommodation. The local councils, the General Council of the Bucharest Municipality or the county councils, as appropriate, may levy fees for the temporary use of public places and visits to museums, memorial houses, historical, architectural and archeological monuments, and the like.

2. Rates from income tax. According to Law 273/2006 on local public finances, as subsequently amended and supplemented, income tax is cashed in the state budget, but every month, $88 \%$ of the amount collected in the previous month is transferred to the local budgets: $47 \%$ goes to the budget of cities, towns, and communes, $13 \%$ is transferred to the county budget, and $22 \%$ is kept in a special account in order to balance the local budgets. 
The $22 \%$ rate is divided into two categories: $27 \%$ is transferred to the county budget, and the remaining $73 \%$ goes to the local budgets of cities, towns, and communes. To do this, the following rule applies: $80 \%$ is distributed in two stages by the director of the county's public finance directorate and $20 \%$ is distributed by the county council's president.

3. Other local own revenues. Other local own revenues include property revenues, revenues from service supplies, fines and penalties, capital revenues, and revenues from financial operations.

\section{The revenue of municipalities in Romania (communes, cities)}

According to article 5 of the local public finance Law 273/2006, the localities ${ }^{6}$ of Romania, i.e., those who have self-administration powers - communes, cities and municipalities, form their budget from (1) own income (i.e., fees, contributions, other payments, other income, and quotas distributed from the income tax), (2) amounts distributed from some income to the stage budget, (3) subsidies from the state budget and other administrations, (4) voluntary transfers other than the subsidies, and (5) various financial operations.

Hence, in addition to their own income, the administrative-territorial units collect also income from the central level, that is, from the state budget. Although the quotas and amounts distributed down from the income tax are formally included in the category of own income (which is fundamentally correct because they are "obtained" locally), in fact, these amounts go to the state budget, and then they revert to the local budgets under this title. One thing to be outlined is that that corporate income tax is not included in the local budget's income as its own income or as a distributed amount or quota. Other income which comes from the central budget consists of the amounts distributed from VAT collections and the subsidies.

In summary, the local budgets include two large categories of income: the own income and the amounts transferred from the central administration; in turn, each of these categories is fed from several sources of funds.

According to article 454 of Law No. 227/2015 on the Tax Code the category of taxes and fees that join exclusively the local budget includes: the tax on buildings, the tax on lands, the tax on vehicles, the fees for certificates, permits and authorizations, the fees for advertising and publicity, the tax on shows, as well as other special or local fees.

However, although collected by the local budget of municipalities, part of the tax on vehicles and the fees for certificates, permits, and authorizations are transferred to the county budgets.

6 By "locality" we will understand any human settlement that has its own administrative capacity. In Romania, we include the concepts of municipalities, towns and communes. 


\section{Revenue of counties in Romania}

Romanian county budgets are not formed directly from taxes and fees paid by the citizens. As indicated below, part of the local taxes and fees are distributed between counties and localities (such as the tax on some cargo carriers, out of which $60 \%$ represents income to the local budget and $40 \%$ is transferred to the county budgets); however, most of the county revenues come from the state budget (amounts distributed from the income tax and amounts distributed from VAT collections).

The counties obtain their income from sources similar to those used by the localities, that is: (1) own income, (2) amounts distributed from some income of the state budget, (3) subsidies from state budget and other administrations, (4) voluntary payments, other than subsidies and (5) various financial operations.

Just like in the case of localities, counties obtain their income from two large sources of funds: their own income and the income offered by the central administration, each with their own sub-categories of sources of funds.

Unlike the municipalities' (cities, communes) own income, a county's own income does not include the amounts collected from exclusive local taxes and fees because they are transferred solely to the local budgets. The most important source of a county's "own" income continues to be the percentages and amounts distributed from the income tax collected by the state budget and the fees for the use of roads, concessions, leases etc.

As regards the county's income from central administration, they are mainly comprised of amounts distributed from VAT amounts collected at the national level (the amount of which is decided, as with localities, in the Law on the annual state budget) and subsidies.

\section{Revenue of local budgets in Poland}

At present, self-government in Poland has a three-tier structure, which comprises municipalities (gminas), counties (powiats), and regions (voivodships). They have been shaped as a result of the decentralization that has been going on for over 25 years. In its major part, the system of financing the territorial self-government is based on the Act of 13 November 2003 on the Revenues of Local Government Units. The Act of $27 \mathrm{Au}-$ gust 2009 regulates the principles of the financial economy on Public Finances, while the structure of taxes and local fees are regulated by several separate Acts of Law. In short, the system of local government finance in Poland has some characteristic features.

As a result of the vertical distribution of tax revenues in the country, municipalities were allocated taxes that were relatively less efficient, the most important of which for local budgets being the property tax. Local taxes were not assigned to the sub-national tiers of government (counties and regions). Their budgets are mainly funded from the local shares of PIT and CIT revenues and fees for administrative services that have 
limited fiscal importance. Common taxes were used in the vertical distribution of revenues: personal income tax and corporate income tax. As a result, shares of the local government across all the tiers in PIT and CIT play an important role. Moreover, according to Polish law, shares in PIT and CIT are treated as own revenues. In counties and regions, their share in income tax is the basic source of their own revenues (for more, see: Guziejewska 2013, 2015).

Local taxes, "common" taxes, and fees are the most important items among municipalities' own revenues. The number of tax titles in municipalities' sources of revenue is quite substantial. In the system, there are also many local fees (for example, stamp duty or administrative charges), which are, in fact, local taxes.

Municipalities obtain the full amount of:

- The real estate tax.

- The agricultural tax.

- The forest tax.

- The tax on transport means (vehicle tax).

- The tax on inheritances and gifts.

- The tax paid by very small firms in the form of a tax card.

- The tax on civil law transactions.

The three last taxes are the source of the municipal budget, but they are collected and administrated by state tax offices. This limits, in different ways, local tax autonomy. The problem has been highlighted by Teszner (2012, pp. 316-319), who observed that some fiscal bodies in the Polish tax administration have limited tax powers for no explainable reason. At the commune level, mayors have no influence on the amounts of revenues collected by tax offices from the three taxes. The Ministry of Finance and some advocates of the doctrine maintain that this solution is determined by the intricate design of the taxes, which require greater competencies to be assessed, collected, and administered than the municipalities and their staff have. It is also argued that tax powers should sit with the central agencies because they guarantee greater consistency of tax decisions and interpretations of tax laws compared with a solution where such powers are dispersed among many local authorities. It seems rational, however, that local authorities are given control over the revenue aspects of taxes that are levied by the state but which are used to fund local budgets (including tax remissions, tax deferments, tax installment payment agreements, etc.). It is also notable that as municipal agencies have long administered many local taxes of comparable complexity and have issued thousands of tax decisions, they have certainly accumulated sufficient experience to take over responsibility for the three taxes. The current, dichotomous structure of tax administration increases the costs of tax collection, delays transfers of funds to lower levels of government, complicates the system of tax reliefs, and reduces the fiscal autonomy of local authorities. Given that, greater devolution of tax powers to local authorities is not only an advisable but also a necessary condition for stronger fiscal decentralization in Poland. 


\section{The scope of local taxes in Romania and Poland: selected aspects and statistical analysis}

The analysis of local government funding sources and local taxes is based on data from the period 2015 to 2017. The true level of fiscal autonomy in Romania is difficult to determine because data on individual local taxes are not available. The fact that only aggregate statistics for the whole local government sector in Romania can be obtained (preventing the analysis of its tiers) is a sign of the strong centralization of the public finance system in this country; likewise, a small proportion of local own revenues (narrowly defined as local taxes and fees) is estimated at only around $16 \%$. The quotas and amounts deducted from income tax are treated as local governments' own revenues, which seems controversial from the perspective of the theory of fiscal federalism.

Table 1. Selected local self-government revenues in total revenues in Romania (million RON and percentage)

\begin{tabular}{|l|r|r|r|r|r|c|}
\hline \multicolumn{1}{|c|}{ Structural indicators } & 2015 & $\begin{array}{c}\text { \% of } \\
\text { total }\end{array}$ & 2016 & $\begin{array}{r}\text { \% of } \\
\text { total }\end{array}$ & 2017 & $\begin{array}{c}\text { \% of } \\
\text { total }\end{array}$ \\
\hline Total & 61.463 & \multicolumn{1}{c|}{100} & 59.511 & \multicolumn{1}{c|}{100} & 62.782 & 100 \\
\hline Subtotal own revenues & 26.699 & 43.5 & 27.850 & 46.8 & 30.692 & 48.9 \\
\hline 1. Taxes, fees, contributions & 9.586 & 15.6 & 9.927 & 16.7 & 10.461 & 16.7 \\
\hline $\begin{array}{l}\text { 2. Quotas and amounts deducted from } \\
\text { income tax }\end{array}$ & 17.113 & 27.9 & 17.923 & 30.1 & 20.231 & 32.15 \\
\hline Sums deducted from value added tax & 21.226 & 34.5 & 20.520 & 34.5 & 23.549 & 37.4 \\
\hline Transfers from state budget & 8.193 & 13.3 & 9.358 & 15.7 & 6.518 & 10.4 \\
\hline $\begin{array}{l}\text { Other revenues } \\
\text { (Amounts received from the EU/other } \\
\text { donors on account of payments made } \\
\text { and pre-financing) }\end{array}$ & 5.345 & 8.7 & 1.790 & 3.0 & 2.023 & 3.2 \\
\hline
\end{tabular}

Source: Curtea de Conturi a României, Sinteza cu privire la rapoartele privind finanțele publice locale pe anul 2016 întocmite la nivelul județelor (p. 6), / Court of Auditors of Romania, Synthesis of reports on local public finances for 2016 drawn up at the level of the counties, http://www.curteadeconturi. ro/Publicatii/Raportul\%20public\%20pe\%20anul\%202017.pdf (accessed: 14.05.2019); http://www. curteadeconturi.ro/Publicatii/Rapoarte_Locale_2016/SintezaLocale2016.pdf (accessed: 14.05.2019).

Romania has successfully managed to achieve the decentralization of public authorities. However, a major challenge for local authorities is the absence of funds.

The main causes of this phenomenon may be summarized as follows:

Most of the fiscal income collected locally goes to the state budget, not to the local budget

First and foremost, there is the profit tax, which accounts for approximately $13 \%$ of the total income to the state budget for 2016, which remains entirely in the hands of the central bodies.

Second, there is income tax (which accounts for more than $24 \%$ of the total budgetary income for 2016); instead of being used by the local communities (which would 
further contribute to the central budget), income tax is transferred to the state budget and then partially reverted to the local budgets.

The trend is falling regarding quotas distributed from the income tax, which are directed to the local budgets. This is partly because of the amendments made to the Law on local public finance by equal ranking laws partly because of annual laws on the state budget (which are lower rank laws). The (annual) law on the state budget, the one that amends the Law on local public finances, is fundamentally unpredictable and surprising every year so that the local authorities are virtually unable to build a solid forecast of the amounts they can count on in order to "balance the local budgets." These amounts basically consist of percentages of the income tax and flat amounts from VAT collections; furthermore, the applicable percentage of the income tax is never the same, and the flat amounts from VAT collections are never predictable or computable, depending on the transparent criteria.

There is also a falling trend regarding part of the other fees which are dedicated to the local budgets, such as the amounts collected from judicial stamp fees, $70 \%$ of which was initially placed in the hands of the local authorities. As of January 1st, 2014 , only $55 \%$ of these amounts are made available to the localities, with the remaining $45 \%$ transferred to the state budget.

Table 2 shows local revenue sources in Poland by tier of government and type of municipal tax. As can be seen, in addition to the sources that are discussed above, there is also a large number of minor taxes characterized by low fiscal efficiency, which is probably determined by their design (the type of taxpayers) but which may also arise from the limited capacity of local administration.

Table 2. Percentage of selected local self-government revenues in total revenues in Poland

\begin{tabular}{|l|c|l|l|c|c|c|}
\hline \multicolumn{2}{|c|}{ Structural indicators } & $\begin{array}{c}\text { Total } \\
\text { (PLN } \\
\text { million) }\end{array}$ & $\begin{array}{c}\text { Gminas } \\
(\%)\end{array}$ & $\begin{array}{c}\text { Cities with } \\
\text { poviat } \\
\text { status (\%) }\end{array}$ & $\begin{array}{c}\text { Powiats } \\
\text { (\%) }\end{array}$ & $\begin{array}{c}\text { Voivodships } \\
\text { (\%) }\end{array}$ \\
\hline Total & 2015 & 199,019 & 44.1 & 35.5 & 11.8 & 8.6 \\
& 2016 & 213,669 & 47.6 & 34.8 & 11.2 & 6.4 \\
& 2017 & 229,879 & 48.4 & 34.2 & 11.1 & 6.3 \\
\hline Subtotal own revenue & 2015 & 103,441 & 42 & 43.3 & 7.7 & 6.9 \\
of which & 2016 & 106,683 & 42.3 & 43.1 & 7.8 & 6.8 \\
& 2017 & 113,245 & 42.4 & 42.7 & 8 & 6.9 \\
\hline Share in income taxes & 2015 & 45,176 & 35.5 & 42.1 & 9.6 & 12.8 \\
(PIT and CIT) & 2016 & 48,549 & 35.9 & 41.8 & 9.6 & 12.6 \\
\hline Tax on real estate & 2017 & 53,267 & 36 & 41.5 & 9.5 & 12.9 \\
\hline & 2015 & 20,171 & 60.6 & 39.4 & $\mathrm{x}$ & $\mathrm{x}$ \\
& 2016 & 20,774 & 60.8 & 39.2 & $\mathrm{x}$ & $\mathrm{x}$ \\
\hline Agricultural tax & 2017 & 21,829 & 61.3 & 38.6 & $\mathrm{x}$ & $\mathrm{x}$ \\
\hline
\end{tabular}




\begin{tabular}{|c|c|c|c|c|c|c|}
\hline \multicolumn{2}{|c|}{ Structural indicators } & $\begin{array}{l}\text { Total } \\
\text { (PLN }\end{array}$ & $\begin{array}{c}\text { Gminas } \\
(\%)\end{array}$ & $\begin{array}{l}\text { Cities with } \\
\text { poviat }\end{array}$ & $\begin{array}{c}\text { Powiats } \\
\text { (\%) }\end{array}$ & $\begin{array}{l}\text { Voivodships } \\
\text { (\%) }\end{array}$ \\
\hline Tax on means of transport & $\begin{array}{l}2015 \\
2016 \\
2017\end{array}$ & $\begin{array}{l}1015 \\
1055 \\
1092\end{array}$ & $\begin{array}{l}68.6 \\
68.7 \\
68.9\end{array}$ & $\begin{array}{l}31.4 \\
31.3 \\
31.1\end{array}$ & $\begin{array}{l}x \\
x \\
x\end{array}$ & $\begin{array}{l}x \\
x \\
x\end{array}$ \\
\hline $\begin{array}{l}\text { Tax on civil law } \\
\text { transactions }\end{array}$ & $\begin{array}{l}2015 \\
2016 \\
2017\end{array}$ & $\begin{array}{l}1749 \\
2172 \\
2551\end{array}$ & $\begin{array}{l}43.9 \\
44.4 \\
40.1\end{array}$ & $\begin{array}{l}56.1 \\
55.6 \\
59.8\end{array}$ & $\begin{array}{l}x \\
x \\
x\end{array}$ & $\begin{array}{l}x \\
x \\
x\end{array}$ \\
\hline Stump duty & $\begin{array}{l}2015 \\
2016 \\
2017\end{array}$ & $\begin{array}{l}409 \\
430 \\
461 \\
\end{array}$ & $\begin{array}{l}37.9 \\
38 \\
36.6\end{array}$ & $\begin{array}{l}62.1 \\
62 \\
63.5\end{array}$ & $\begin{array}{l}x \\
x \\
x\end{array}$ & $\begin{array}{l}x \\
x \\
x\end{array}$ \\
\hline Revenue from property & $\begin{array}{l}2015 \\
2016 \\
2017 \\
\end{array}$ & $\begin{array}{l}7463 \\
7354 \\
7439 \\
\end{array}$ & $\begin{array}{l}35.6 \\
38.8 \\
42.1 \\
\end{array}$ & $\begin{array}{l}58.1 \\
54.5 \\
51 \\
\end{array}$ & $\begin{array}{l}4.1 \\
4.2 \\
4.2 \\
\end{array}$ & $\begin{array}{l}2.2 \\
2.5 \\
2.7 \\
\end{array}$ \\
\hline $\begin{array}{l}\text { Funds for financing own } \\
\text { tasks from other sources }\end{array}$ & $\begin{array}{l}2015 \\
2016 \\
2017 \\
\end{array}$ & $\begin{array}{r}1384 \\
561 \\
614 \\
\end{array}$ & $\begin{array}{l}74.8 \\
52.8 \\
57.5 \\
\end{array}$ & $\begin{array}{l}14.7 \\
23.4 \\
22 \\
\end{array}$ & $\begin{array}{r}6.6 \\
15.3 \\
15.2 \\
\end{array}$ & $\begin{array}{l}3.9 \\
8.7 \\
5.2\end{array}$ \\
\hline Specific grants & $\begin{array}{l}2015 \\
2016 \\
2017\end{array}$ & $\begin{array}{l}44,235 \\
53,949 \\
62,353\end{array}$ & $\begin{array}{l}42.3 \\
56.2 \\
57.7\end{array}$ & $\begin{array}{l}26.9 \\
26.1 \\
24.7\end{array}$ & $\begin{array}{r}12.9 \\
9.7 \\
9.7\end{array}$ & $\begin{array}{l}17.9 \\
8 \\
7.7\end{array}$ \\
\hline $\begin{array}{l}\text { General subvention from } \\
\text { the state budget }\end{array}$ & $\begin{array}{l}2015 \\
2016 \\
2017\end{array}$ & $\begin{array}{l}51,343 \\
53,036 \\
54,281\end{array}$ & $\begin{array}{l}49.5 \\
49.7 \\
49.9\end{array}$ & $\begin{array}{l}27.1 \\
27.3 \\
27.2\end{array}$ & $\begin{array}{l}19.6 \\
19.3 \\
18.9\end{array}$ & $\begin{array}{l}3.8 \\
3.7 \\
3.0\end{array}$ \\
\hline
\end{tabular}

Source: own calculations and Statistical Yearbook of the Republic of Poland, Warsaw 2016-2018.

Countries where advanced fiscal decentralization is more advanced are faced with the problem of local tax competition. In Poland, the problem has been addressed in the work on local fiscal policies by Swianiewicz and Łukomska (2016, pp. 37-42). As the law stands, Polish gminas can grant additional reliefs and exemptions from local taxes and set tax rates below the maximum rates enacted by the national parliament, but they have no influence on the design of PIT or CIT. Despite this uniform legislative framework, they found differences between fiscal policies pursued by individual gminas and reported that the fiscal burden in a gmina is influenced by the level of taxation in contagious units. However, contrary to the authors' expectations, the statistical evidence of tax competition is strongest not in the case of tax with a mobile tax base, but in the case of tax on agriculture, followed by tax on housing properties. This suggests that the competition is more related to the 'yardstick competition' and electoral motives than the classic competition for a mobile tax base.. There is very little competition for a mobile tax base.

Apart from statistics, another problem is real citizens' interests and rights with reference to public administration. Analyses of mechanisms and instruments of participatory democracy in Romania shows the gap between the decision making transparency and public administration activities (see: Alexandru 2018, pp. 146-157). 


\section{Conclusions}

The comparison of public finance systems in Poland and Romania, which have achieved different stages of decentralization processes, shows that administrative capacity may hamper or even inhibit decentralization as well as fiscal decentralization. The evidence of reform shows that the administrative capacity requirements did not lead to successful decentralization or institution building. The discussion above emphasizes the significance of administrative capacity in two EU countries at different levels of decentralization and enriches the existing literature, which concentrates mostly on two broader groups of countries: developed and developing countries. The added value of the article is both theoretical and practical. It enriches the theory of fiscal federalism in the context of unitary countries, and it provides officials and politicians with guidance for implementing some strategies in practice. Romania can learn from the Polish lesson in the area of local tax administration processes.

There is still a long way to go before fiscal decentralization is achieved in Romania. Although assumed legislative, the principle of financing has no consistency anymore due to the equalization system. This outdated system abounds with unnecessary complications and leaves room for arbitrage in the allocation of public money. Basically, the public money is distributed from top to bottom, from the center to the periphery, although they are collected locally and are produced by local, sub-national tiers. Reversing the current system of distributing public money, so that it circulates from the bottom up, from where it is produced to the higher levels, could correct many errors of the current system.

It seems that the main problem in Romania is the lack of political will to continue financial decentralization as well as a large number of 'shared taxes' that are levied and administered by the central government. The degree to which the situation is caused by limited administrative capacity is difficult to determine. The delay in fiscal decentralization is caused by the presumption of local authorities' incompetence, which also hinders and prevents the full and true implementation of the principle of subsidiarity underlying the European philosophy of decentralization. A symbol of the strong centralization of the public finance system in Romania is the unavailability of financial data on individual tiers of local government.

In Poland, there is the barrier of insufficient devolution of tax powers to the lower levels of government. In particular, local authorities have no jurisdiction over taxes that are more complicated in legal and financial terms, and they have very limited rights to design municipal taxes and set the levels. Their prerogatives in this area are limited to reducing the maximum tax rates set by the central government and offering taxpayers reliefs and exemptions. The system is known in Poland as a limited power of taxation. Romania can draw on the Polish experience in the area of real estate tax and shared taxes; if the fiscal autonomy for these instruments is very limited, many economic, social, and political problems arise. This study also reinforces the hypothesis about the great importance of income independence in decentralization processes 
and shows the asymmetry in the distribution of funds between Polish municipalities, powiats, and voivodships (see Table 2). The redistribution is also based on the administrative capacity of the levels of local self-government.

In both countries, limited administrative capacity is responsible for the failure of various policies and reforms, including sectorial decentralization. It seems that the guidance of the EU regarding institution-building did not lead to the construction of "lasting and stable institutions."

On the one hand, the lack of a strong and coherent model of the EU administrative capacity was identified, and on the other hand, there is EU ignorance of the preferences of domestic political actors regarding the institution-building exercise. The construction of administrative capacity still needs a consensus that represents the will of the politicians and the public; otherwise, the EU's conditionality will continue to lead to frequent changes in the laws and uncertainty.

\section{References}

Ahmad, E., Brosio G. (eds.) (2015), Handbook of multilevel finance, Edward Elgar Publishing.

Alexandru, D.G. (2018), Uneven Progress of the Participatory Democracy in Romania, „Acta Universitatis Lucian Blaga 146”, Iurisprudentia, Sibiu.

Bird, R. (1993), Treading the fiscal labyrinth: some issues in fiscal decentralization, "National Tax Journal", Vol. 46, No. 2.

Borodo, A. (1997), Samorzad terytorialny. Sysytem prawno-finansowy, Wydawnictwo Naukowe PWN, Warszawa.

Brennan, G., Buchanan, J.M. (1980), The Power to Tax: Analytical Foundations of a Fiscal Constitution, Cambridge University Press, Cambridge.

Breton, A. (1996), Competitive Governments. An Economic Theory of Politics and Public Finance, Cambridge University Press, New York.

Dimitrova, A. (2002), Enlargement, Institution-building and the EU's Administrative Capacity Requirement, West European Politics, Vol. 25 (4). https://doi. org/10.1080/713601647

Dragos, D., Neamțu, B. (2007), Reforming local public administration in Romania: trends and obstacles, "International Review of Administrative Sciences", Vol. 73 (4), pp. 629-648. https://doi.org/10.1177/0020852307083464

El-Taliawi, O.G., Van Der Wal, Z. (2019), Developing administrative capacity: an agenda for research and practice, "Policy Design and Practice", Vol. 2 (3), pp. 243-257, Taylor \& Francis Group. https://doi.org/10.1080/25741292.2019.1595916

Framework - Law on Decentralization No. 195/2006, Official Monitor of Romania No. 453 of 25 May 2006; Law 273/2006 on local public finance Official Monitor of Romania No. 618 of 18 July 2006.

Gargan, J.J. (1981), Consideration of Local Government Capacity, "Public Administration Review”, Vol. 41 (6). https://doi.org/10.2307/975741 
Guziejewska, B. (2013), Intergovernmental fiscal relations. Theoretical aspects and Poland's experience, Financial Internet Quarterly, "e-Finanse" Vol. 9, No. 3.

Guziejewska, B. (2015) Designing a revenue structure in local self-government entities in Poland: taxes versus grants, "Equilibrium. Quarterly Journal of Economics and Economic Policy”, Vol. 10, Issue 3. https://oi.org/10.12775/EQUIL.2015.024

Howlett, M. (2019), Designing Public Policies. Principles and Instruments, Routledge, Taylor \& Francis Group, London.

Kuhlmann, S., Wollmann, H. (2014), Introduction to Comparative Public Administration. Administrative Systems and Reforms in Europe, Edward Elgar.

Kulesza, M., Sześciło, D. (2012), Local Government in Poland, [in:] A.M. Moreno (ed.), Local Government in the Member States of the European Union: A Comparative Legal Perspective, Madrid 2012.

Madrid European Council (1995), http://www.europarl.europa.eu/summits/mad1_ en.htm (accessed: 29.08.2018)

Musgrave, R.A., Musgrave, P.B. (1980), Public Finance in Theory and Practice, Third Edition, McGraw-Hill Book Company.

OECD (1995), Public Management Developments, Paris.

Petak, Z. (2006), Policy in a Transitional Context: Performing Decentralization in Croatia, [in:] Colebatch, C. (ed.) The Work of Policy: An International Survey, Lanham: Lexington Books.

Swianiewicz, P., Łukomska, J. (2016), Local Tax Competition in Poland, MISCELLANEA GEOGRAPHICA - Regional Studies On Development, Vol. 20, No. 3. https://doi.org/10.1515/mgrsd-2016-0018

Ustawa $z$ dnia 13 listopada 2003 r. o dochodach jednostek samorzadu terytorialnego, Dz.U. No. 203 z 2003 r., poz. 1966 (Act on Local Government Revenues).

Ustawa z dnia 27 sierpnia 2009 r. o finansach publicznych, Dz.U. No. 157 z 2009 r., poz. 1240 (Act on Public Finance).

Teszner, K. (2012), Administracja podatkowa i kontrola skarbowa w Polsce, Wolters Kluwer, Warszawa.

Thijs, N., Hammerschmid, G. and Palaric, E. (eds.) (2017), A comparative overview of public administration characteristics and performance in EU28, European Commission. 


\section{Streszczenie}

\section{Możliwości administarcyjne jako ograniczenie decentralizacji fiskalnej. Przypadek Rumunii i Polski}

w artykule zajmujemy się problemem możliwości administracyjnych jako jednego z głównych wymogów, które spełnić musiały kraje w procesie przyłączania się do Unii Europejskiej i decentralizacji sektora publicznego i finansów publicznych. Przedstawiamy wybrane problemy decentralizacji w dwóch krajach: Polsce i Rumunii. Celem artykułu jest przedyskutowanie teoretycznych i praktycznych elementów dotyczących możliwości administracyjnych jako bariery decentralizacji fiskalnej jak również porównanie ich z poziomem zaawansowania decentralizacji. Oba kraje różnią się bowiem zakresem i stopniem procesu decentralizacji

Z analizy porównawczej procesów decentralizacji o różnym stopniu zaawansowania wynika, że możliwości administracyjne mogą być elementem hamującym decentralizację fiskalną w różnych aspektach omawianych procesów. W przypadku Polski barierą jest dalsza decentralizacja podatków gminnych o bardziej złożonej konstrukcji prawno-finansowej. W Rumunii głównym problemem pozostaje głębsza decentralizacja kompetencji oraz faktyczna niezależność finansowa samorządu terytorialnego. W istocie chodzi więc, w tym kraju, o faktyczną implementację zasady subsydiarności.

Słowa kluczowe: administracja publiczna, podatki lokalne, decentralizacja fiskalna, samorząd terytorialny 